\title{
Metal ring on a permanent molar: a rare occurrence
}

\author{
Triveni N Nalawade, ${ }_{1}^{1}$ Rachappa Mallikarjuna, ${ }^{2}$ Gopika Sharma, ${ }_{1}^{3}$ Kalyan Chakravarthy ${ }^{2}$
}

${ }^{1}$ Department of Pediatric and Preventive Dentistry, Anubhai Patel Dental College and Hospital, ORI, Vadodara, Gujarat, India

${ }^{2}$ Department of Pedodontics and Preventive Dentistry, K.M. Shah Dental College and Hospital, Vadoadara, Gujarat, India

${ }^{3}$ Department of Pedodontics and Preventive Dentistry, Jodhpur Dental College, Jodhpur, Rajasthan, India

\section{Correspondence to}

Dr Rachappa Mallikarjuna, mmrachappa@gmail.com
To cite: Nalawade TN, Mallikarjuna R, Sharma G, et al. BMJ Case Reports Published online: 28 November 2012 doi:10.1136/bcr-2012007750

\section{DESCRIPTION}

Foreign bodies are commonly found in the oral cavity ${ }^{1}$ of children and are discovered by dentist during the routine examination. ${ }^{2}$ An 11-year-old boy with parent reported with a rare chief complaint of a metal ring getting stuck on to the tooth from past 5 days. On interviewing the child and parent it was revealed that the child was playing with the metal ring and during the play unknowingly the child had put the ring into the mouth and the ring got stuck. The parent tried to remove the ring but without success. The parent was a motor garage owner and it was confirmed that the source of the metal ring was from the motor garage.

On examination, a metal ring was found to be on the mandibular left first permanent molar (figure 1).

The buccal gingiva of mandibular left first permanent molar was found injured which clearly shows that an attempt had been made to remove the metal ring (figure 2).

The treatment was explained to the patient and parent and the metal ring was removed using a band remover, which is routinely used in paediatric dentistry and orthodontics.

On removing the metal ring, gingiva surrounding the mandibular left first permanent molar was found to be inflamed due to the pressure by the

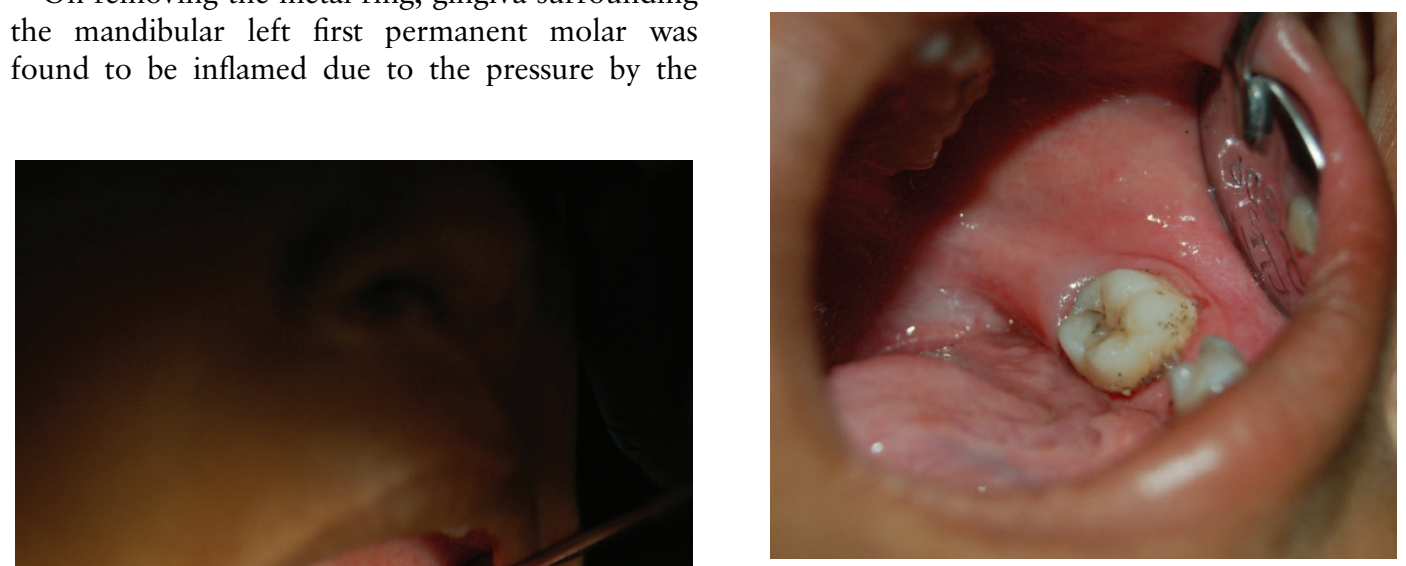

Figure 1 Metal ring on left mandibular first molar.
Figure 3 Inflamed gingiva due to the pressure by

metal ring and food accumulation.
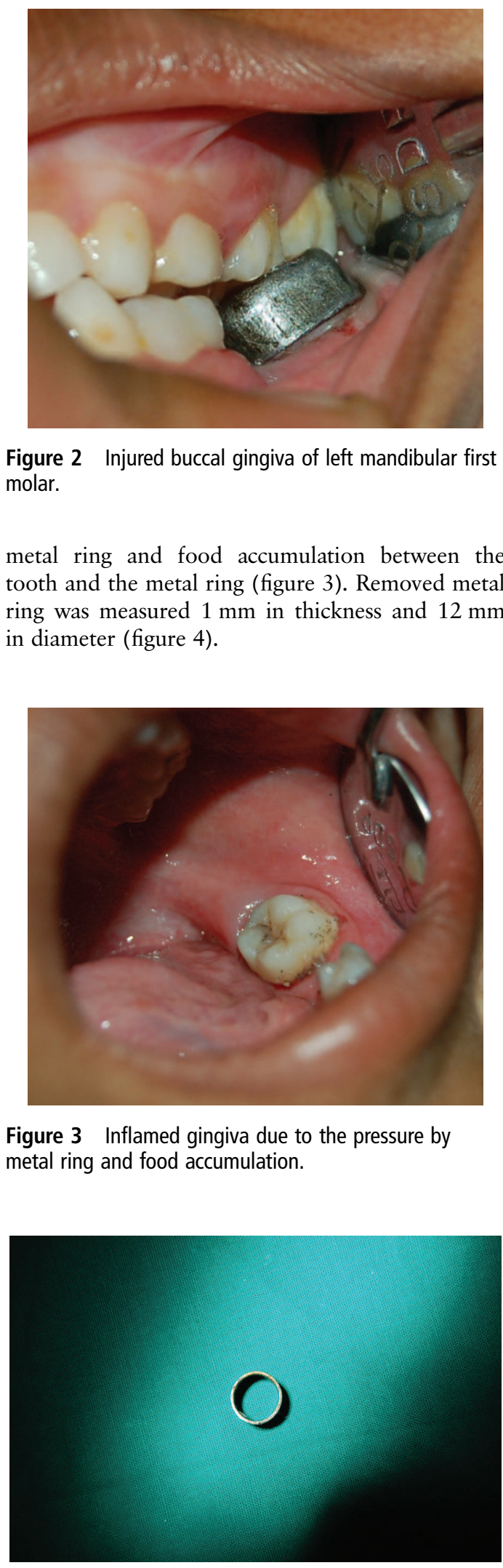

Figure 2 Injured buccal gingiva of left mandibular first molar.

metal ring and food accumulation between the tooth and the metal ring (figure 3 ). Removed metal ring was measured $1 \mathrm{~mm}$ in thickness and $12 \mathrm{~mm}$ in diameter (figure 4).

Figure 4 Removed metal ring. 
Health professionals should be alert to the presence of foreign bodies, and educational campaigns should be conducted for emphasising the dangers of improper use of teeth. ${ }^{3}$

\section{Learning points}

Dental surgeons should be alert to the presence of foreign bodies and their complications in the oral cavity of children.

- Children and parents should be educated about dangers of improper use of teeth.

- Parents should be educated so that very small objects are kept out of reach of children.
Competing interests None.

Patient consent Obtained.

\section{REFERENCES}

1 Ram D, Peretz B. Tongue piercing and insertion of metal studs: three cases of dental and oral consequences. ASDC J Dent Child 2000;67:326-9.

2 Yassin OM, Hattab FN. Unusual nasal foreign body detected on routine dental radiography: case report. J Clin Pediatr Dent 1996;20:155-7.

3 Pomarico L, Primo LG, de Souza IP. Unusual foreign body detected on routine dental radiograph. Arch Dis Child 2005;90:825.

Copyright 2012 BMJ Publishing Group. All rights reserved. For permission to reuse any of this content visit http://group.bmj.com/group/rights-licensing/permissions.

BMJ Case Report Fellows may re-use this article for personal use and teaching without any further permission.

Become a Fellow of BMJ Case Reports today and you can:

- Submit as many cases as you like

- Enjoy fast sympathetic peer review and rapid publication of accepted articles

- Access all the published articles

- Re-use any of the published material for personal use and teaching without further permission

For information on Institutional Fellowships contact consortiasales@bmjgroup.com

Visit casereports.bmj.com for more articles like this and to become a Fellow 